\title{
PROSPEK SWASEMBADA BERAS DI PROVINSI KALIMANTAN TIMUR
}

\author{
Wajar Mey Handani ${ }^{1}$, Nunung Kusnadi ${ }^{2}$, dan Dwi Rachmina ${ }^{3}$ \\ 1) Program Magister Sains Agribisnis, Sekolah Pascasarjana, Institut Pertanian Bogor \\ 2,3Departemen Agribisnis, Fakultas Ekonomi dan Manajemen, Institut Pertanian Bogor \\ Jl. Kamper Wing 4 Level 5 Kampus IPB Dramaga, Indonesia \\ e-mail: 1)mayhandani@gmail.com
}

(Diterima 23 Juli 2020/Revisi 14 Agustus 2020/Disetujui 30 Agustus 2020)

\begin{abstract}
Rice self-sufficiency in Indonesia remains a national priority program since rice is a staple food of the majority of the population. This national program has become an economic development agenda in almost all local governments at the provincial and district levels. East Kalimantan Province is one of the provinces that set the rice self-sufficiency on the local medium-term planning (RPJMD) 2013-2018. This research generally aimed at analyzing the prospect of rice self-sufficiency in East Kalimantan Province. Specifically, the research aimed to measure the potential for developing rice in East Kalimantan Province and to analyze the production technical efficiency of rice farming. The data used in this research were national and provincial agriculture land area and 337 units of rice farm from Agricultural Census 2013. Using LQ (Location Quotient) method indicated that economically rice was not a basic commodity of East Kalimantan Province. At the provincial level, there were only two out of four districts that had rice as a basic commodity. Stochastic production frontier analysis showed that the technical efficiency of rice production was 0.64 , which indicated that rice production in the province was 36 per cent below its production frontier. Planting patterns and land status significantly improved technical efficiency. From this research can be concluded that the self-sufficiency program in East Kalimantan Province was not supported by regional potential of rice production nor by technically efficient rice production at the farm level.
\end{abstract}

Keywords: basic commodity, location quotient, stochastic frontier analysis, technical efficiency, translog

\begin{abstract}
ABSTRAK
Swasembada beras di Indonesia tetap menjadi program prioritas nasional, dikarenakan beras menjadi makanan pokok sebagian besar penduduk. Program nasional ini telah menjadi agenda pembangunan ekonomi di hampir semua pemerintah daerah di tingkat provinsi maupun kabupaten. Provinsi Kalimantan Timur menjadi salah satu provinsi yang menetapkan swasembada beras pada RPJMD 2013-2018. Penelitian ini umumnya bertujuan menganalisis prospek swasembada beras di Provinsi Kalimantan Timur. Secara khusus, penelitian ini bertujuan untuk mengukur potensi pengembangan padi di Provinsi Kalimantan Timur dan menganalisis efisiensi teknis produksi pertanian padi. Penelitian ini menggunakan data luas lahan pertanian nasional dan provinsi, dan 337 unit petani padi dari Sensus Pertanian 2013. Menggunakan metode LQ (Location Quotient) menunjukkan bahwa padi secara ekonomi bukan komoditas basis Provinsi Kalimantan Timur. Di tingkat provinsi, hanya ada dua dari empat kabupaten yang berpotensi mengembangkan padi sebagai komoditas basis. Analisis produksi efisiensi teknis frontier stochastic sebesar 0,64, yang menunjukkan bahwa produksi padi di provinsi ini masih 36 persen di bawah batas produksinya. Pola penanaman dan status lahan secara signifikan meningkatkan efisiensi teknis. Dari penelitian ini dapat disimpulkan bahwa program swasembada di Provinsi Kalimantan Timur tidak didukung oleh potensi produksi padi regional maupun oleh produksi padi yang efisien secara teknis di tingkat petani.
\end{abstract}

Kata kunci: efisiensi teknis frontier stochastic, komoditas basis, location quotient, translog 


\section{PENDAHULUAN}

Program swasembada beras tetap menjadi program prioritas secara nasional. Hal ini mengingat beras masih dikonsumsi mayoritas penduduk Indonesia sebagai makanan pokok. Oleh karena itu, permintaan beras akan cenderung semakin meningkat sejalan dengan meningkatnya jumlah penduduk. Kasryno et al. (2011) menjelaskan bahwa permintaan beras secara nasional terus mengalami peningkatan sekitar 1,00 persen pertahun hingga tahun 2050. Luas lahan baku sawah nasional dari tahun 2018 sampai 2019 menunjukkan peningkatan sebesar 0,05 persen, namun di sisi lain luas panen dan produksi padi menurun sebesar 6,15 persen dan 7,76 persen (BPS 2019).

Kemampuan swasembada pemerintah ditunjukkan oleh kemampuan menghasilkan produksi yang responsif dan antisipatif guna pemenuhan kebutuhan konsumsi masyarakat menggunakan faktor produksi yang tersedia. Swasembada beras di Indonesia pernah diupayakan dengan mengurangi konsumsi beras masyarakat. Sejak tahun 60-an Indonesia telah mengupayakan diversifikasi pangan tetapi program tersebut tidak seperti yang diharapkan. Faktor yang menghambat diversifikasi pangan adalah konsep makan, dikatakan belum makan jika belum makan nasi. Pola konsumsi pangan pokok masyarakat yang semula pola beragam berubah menjadi pola tunggal yaitu mengkonsumsi beras (Ariani 2010). Perhatian pemerintah untuk mencapai swasembada beras lebih terpusat pada kemampuan dalam memproduksi padi. Pemerintah menargetkan swasembada beras yaitu pemenuhan kebutuhan beras dari produksi dalam negeri sekitar 90 persen. Pemerintah menetapkan berbagai langkah dan kebijakan untuk dapat mewujudkan swasembada beras tersebut melalui upaya peningkatan produksi padi nasional. Implementasi program swasembada beras tersebut dilakukan di sebagian besar provinsi dan kabupaten. Pemerintah telah menetapkan daerah-daerah sentra pengembangan padi yang dituangkan dalam keputusan Menteri Pertanian Republik Indonesia Nomor 472/Kpts/RC.040/6/2018 tentang lokasi kawasan pertanian nasional. Berdasarkan keputusan menteri tersebut terdapat 32 provinsi dan 289 kabupaten yang ditetapkan sebagai sentra produksi padi atau lokasi kawasan pertanian nasional untuk komoditas padi.

Provinsi Kalimantan Timur merupakan salah satu provinsi yang mengagendakan capaian swasembada beras, seperti tercantun pada RPJMD Kaltim 2013-2018 dalam Peraturan Gubernur (Pergub) Kaltim Nomor 50 Tahun 2016. Indikator pencapaian swasembada beras yang dicanangkan Provinsi Kalimantan Timur sesuai Pergub tersebut yaitu rasio pemenuhan kebutuhan beras sebesar 85 persen. Hingga saat ini, kebijakan tersebut masih relevan digunakan mengingat dalam Peraturan Daerah Provinsi Kalimantan Timur Nomor 2 Tahun 2019 tentang RPJMD Provinsi Kalimantan Timur Tahun 2019-2023, tetap mengupayakan swasembada pangan dan mewujudkan ketahanan pangan khususnya beras. Kebijakan tersebut juga didukung dengan ditetapkannya tiga lokasi kawasan pengembangan komoditas padi di Kalimantan Timur, sesuai Kementan (2018) tersebut di atas, yaitu Kabupaten Kutai Kartanegara, Kabupaten Penajam Paser Utara, dan Kabupaten Paser.

Prospek swasembada beras di Provinsi Kalimantan Timur menarik untuk diteliti mengingat Kalimantan Timur selama ini dikenal bukan sentra produksi padi. Produksi dan produktivitas di Kalimantan Timur lebih rendah dari produksi dan produktivitas nasional. Areal pertanian di Provinsi Kalimantan Timur didominasi 85 persen oleh tanaman perkebunan. Sampai saat ini, produksi beras Kalimantan Timur hanya mampu memenuhi sekitar 73,54 persen kebutuhan konsumsi berasnya dengan kecenderungan menurun 0,89 persen per tahun (Dispertan 2018). Luas panen padi mengalami penurunan sebesar 4,80 ha per tahun dan produksi padi juga cenderung menurun sebesar 5,80 ton per tahun (BPS Kaltim 2018). Berdasarkan kondisi tersebut, menarik untuk diteliti prospek Kalimantan Timur mencapai swasembada beras dengan memperhitungkan potensi 
wilayah dalam meproduksi padi. Padi di Provinsi Kalimantan Timur diproduksi oleh sejumlah besar usahatani kecil yang dikelola dalam bentuk usahatani keluarga. Kemampuan wilayah untuk swasembada beras, dengan demikian, ditentukan juga oleh produksi dan produktivitas padi di level usahatani tersebut.

Berdasarkan uraian di atas, secara umum penelitian ini bertujuan untuk menganalisis prospek swasembada beras di Provinsi Kalimantan Timur. Secara khusus penelitian ini bertujuan menganalisis potensi wilayah dalam memproduksi padi, dan menganalisis efisiensi teknis usahatani padi di Provinsi Kalimantan Timur.

\section{METODE}

\section{PENGUMPULAN DATA DAN ANALISIS}

Data yang digunakan dalam penelitian ini yaitu data sekunder, terdiri atas data time series areal tanaman pangan, hortikultura, dan perkebunan, dan data cross section usahatani padi. Data areal tanaman diperoleh dari dokumen Kementerian Pertanian RI tahun 2013-2017, data BPS dan Laporan Dinas Pertanian Tanaman Pangan dan Hortikultura Provinsi Kalimantan Timur tahun 2017 dan 2018, serta SIDATA (Sistem Informasi Data) Kalimantan Timur tahun 2013-2017. Data usahatani padi menggunakan data Sensus Pertanian 2013 Survey Rumah Tangga Usaha Tanaman Padi oleh BPS dengan jumlah petani sampel 337 unit.

\section{METODE ANALISIS}

Potensi wilayah Provinsi Kalimantan Timur dalam memproduksi padi dianalisis dengan metode Location Quotient (LQ) untuk menentukan komoditas basis. Komoditas basis diukur dalam dua level wilayah, yaitu level wilayah nasional dan level wilayah provinsi. LQ dihitung berdasarkan luas lahan pertanian nasional dan luas lahan pertanian provinsi. Pengukuran LQ menggunakan rumus Hendayana (2003), sebagai berikut:
LQ pertanian tingkat nasional:

$$
\mathrm{LQ}=\frac{L p i / \Sigma L p p i}{L k n i / \Sigma L p n}
$$

Keterangan:

$L p_{i}=$ luas lahan komoditi $i$ di provinsi $i$ pada tahun tertentu (ha)

$\Sigma L p p_{i}=$ total luas lahan sektor pertanian di provinsi $i$ pada tahun tertentu (ha)

$L k n_{i}=$ luas lahan komoditi $i$ di tingkat nasional pada tahun tertentu (ha)

$\Sigma L p n=$ total luas lahan sektor pertanian nasional pada tahun tertentu (ha)

LQ pertanian tingkat provinsi:

$$
\mathrm{LQ}=\frac{L k i / \Sigma L p k}{L k p i / \Sigma L p p}
$$

Keterangan:

$L k_{i}=$ luas lahan komoditi $i$ di kabupaten pada tahun tertentu (ha)

$\Sigma L p_{k}=$ total luas lahan sektor pertanian di kabupaten pada tahun tertentu (ha)

$L k p_{i}=$ luas lahan komoditi $i$ di tingkat provinsi pada tahun tertentu (ha)

$\Sigma L p_{p}=$ total luas lahan sektor pertanian tingkat provinsi pada tahun tertentu (ha)

Potensi wilayah dalam mengembangkan komoditas didasarkan pada besaran LQ relatif antar komoditas di tingkat provinsi dan kabupaten. Komoditas dapat dikatakan sebagai basis jika memiliki nilai LQ lebih dari satu (LQ>1).

Efisiensi teknis di dalam penelitian ini menggunakan konsep efisiensi Farrell (1957) dan Coelli et al. (2005). Fungsi produksi padi menggunakan bentuk fungsi produksi translog (Christensen et al. 1973), diduga dengan metode stochastic frontier. Model fungsi produksi translog dalam penelitian ini dirumuskan sebagai berikut:

$\ln \mathrm{Y}=\beta 0+\beta 1 \ln \mathrm{X} 1+\beta 2 \ln \mathrm{X} 2+\beta 3 \ln \mathrm{X} 3+\beta 4 \ln \mathrm{X} 4$ $+\beta 5 \ln X 5+\beta 6 \ln X 6+\beta 11^{*} 0.5 \ln \mathrm{X} 12+$ $\beta 22 * 0.5 \ln X 22+\beta 33^{*} 0.5 \ln X 32+\beta 44^{*} 0.5 \ln X 42+$ $\beta 55^{*} 0.5 \ln X 52+\beta 66^{*} 0.5 \ln X 62+\beta 12 \ln X 1 \ln X 2+$ $\beta 13 \ln X 1 \ln X 3+\beta 14 \ln X 1 \ln X 4+\beta 15 \ln X 1 \ln X 5+$ $\beta 16 \ln X 1 \ln X 6+\beta 23 \ln X 2 \ln X 3+\beta 24 \ln X 2 \ln X 4+$ $\beta 25 \ln X 2 \ln X 5+\beta 26 \ln X 2 \ln X 6+\beta 34 \ln X 3 \ln X 4+$ 




dari hasil pendugaan fungsi produksi translog dapat dihitung elastisitas produksi menurut rumus Guo dan Marchand (2014)

$$
\partial \ln Y / \partial \ln X j=\beta j+\beta j j \ln X j+\Sigma \beta j k \ln X k
$$

Selanjutnya tingkat efisiensi teknis dan fungsi inefisiensi teknis mengikuti metode Coelli et al. (2005) yaitu

$$
\mathrm{TEi}=\exp (-\mathrm{E}[\mathrm{ui} \mid \dot{\mathrm{i}}]) \mathrm{i}=1,2,3, \ldots, \mathrm{N}
$$

dengan,

TEi = efisiensi teknis usahatani ke-i $\exp (-E[u i \mid c \dot{i}])=$ nilai harapan (mean) dari ui dengan syarat ċi

Ukuran nilai efisiensi teknis usahatani berkisar antara nol sampai dengan satu $(0 \leq \mathrm{TE} \leq 1)$. Coelli et al. (2005) menyatakan usahatani yang efisien secara teknis jika mencapai nilai TE $>0,70$.

Nilai parameter distribusi efek inefisiensi teknis produksi padi dianalisis secara terpisah. Model estimasi efek inefisiensi teknis yang digunakan dapat dilihat pada persamaan berikut:

$u i=\delta 0+\delta 1 Z 1+\delta 2 Z 2+\delta 3 Z 3+\delta 4 Z 4+\delta 5 Z 5+$ $\delta 6 Z 6$
Keterangan:

ui $=$ efek inefisiensi teknis

$\mathrm{Z1}=$ kredit (persentase $\%$ )

$\mathrm{Z} 2$ = dummy penyuluh (1=mengikuti, $0=$ tidak mengikuti)

Z3 = dummy irigasi $(1=$ irigasi, $0=$ non irigasi)

$\mathrm{Z} 4$ = dummy pola tanam $(1=$ lebih dari $1 \mathrm{kali}$, $0=$ satu kali)

$\mathrm{Z5}=$ dummy alat (1=traktor, $0=$ lainnya)

$\mathrm{Z6}=$ dummy status lahan $(1=$ milik sendiri, $0=$ sewa)

$\delta 0=$ intersep

$\delta \mathrm{i}=$ parameter yang diduga

Nilai koefisien yang diharapkan adalah $\delta 1, \delta 2, \delta 3, \delta 4, \delta 5, \delta 6<0$ (berpengaruh negatif terhadap inefisiensi usahatani atau positif terhadap efisiensi usahatani.

\section{HASIL DAN PEMBAHASAN \\ PROSPEK SWASEMBADA BERAS BERDASARKAN POTENSI WILAYAH DI PROVINSI KALIMANTAN TIMUR}

Swasembada beras diartikan sebagai kemampuan mencukupi kebutuhan beras yang berasal dari hasil produksi wilayah sendiri. Seperti telah dikemukakan di atas, prospek swasembada dilihat dari potensi pengembangan komoditas di wilayah menggunakan kriteria LQ. LQ menunjukkan komoditas basis, memiliki daya saing dan keunggulan komparatif (Setiyanto 2013), sehingga berpotensi untuk dikembangkan di wilayah.

Hasil perhitungan LQ komoditas pertanian di Provinsi Kalimantan Timur dapat dilihat pada Tabel 1. Tabel tersebut menunjukkan nilai LQ padi jauh lebih kecil dibandingkan dengan nilai LQ komoditas lain. Berdasarkan nilai LQ tersebut, padi bukan merupakan komoditas basis Provinsi Kalimantan Timur. Seperti telah di kemukakan sebelumnya bahwa Provinsi Kalimantan Timur selama ini dikenal sebagai sentra produksi perkebunan. Pada Tabel 1 terlihat 
Tabel 1. Nilai LQ Komoditas Pertanian di Provinsi Kalimantan Timur Tahun 2013-2017

\begin{tabular}{lcccccc}
\hline \multicolumn{1}{c}{ Komoditas } & \multicolumn{3}{c}{ Tahun } & \multicolumn{2}{c}{ Rata-rata } \\
\cline { 2 - 5 } \multicolumn{1}{c}{ Tanaman Pangan } & $\mathbf{2 0 1 3}$ & $\mathbf{2 0 1 4}$ & $\mathbf{2 0 1 5}$ & $\mathbf{2 0 1 6}$ & $\mathbf{2 0 1 7}$ & LQ \\
Padi sawah & & & & & & \\
padi ladang & 0,44 & 0,26 & 0,22 & 0,15 & 0,19 & 0,25 \\
padi total & 0,65 & 1,19 & 1,17 & 0,84 & 0,79 & 0,93 \\
Jagung & 0,45 & 0,34 & 0,30 & 0,20 & 0,24 & 0,30 \\
Kedelai & 0,04 & 0,03 & 0,03 & 0,04 & 0,08 & 0,04 \\
Kacang hijau & 0,14 & 0,06 & 0,06 & 0,07 & 0,09 & 0,09 \\
Kacang tanah & 0,16 & 0,08 & 0,03 & 0,03 & 0,03 & 0,07 \\
Ubi kayu & 0,18 & 0,11 & 0,08 & 0,06 & 0,08 & 0,10 \\
Ubi jalar & 0,22 & 0,14 & 0,11 & 0,11 & 0,19 & 0,15 \\
$\quad$ Perkebunan & 0,65 & 0,36 & 0,29 & 0,21 & 0,37 & 0,38 \\
Kakao & & & & & & \\
Lada & 0,38 & 0,22 & 0,20 & 0,18 & 0,19 & 0,23 \\
Kopi & 2,96 & 1,61 & 1,64 & 1,37 & 1,31 & 1,78 \\
Karet & 0,20 & 0,10 & 0,12 & 0,09 & 0,09 & 0,12 \\
Sawit & 1,59 & 0,91 & 0,80 & 0,73 & 0,78 & 0,96 \\
Kelapa & 5,64 & 3,16 & 3,18 & 3,47 & 2,98 & 3,69 \\
Nilam & 0,52 & 0,30 & 0,27 & 0,24 & 0,25 & 0,32 \\
Pala & 0,01 & 0,00 & 0,01 & 0,01 & 0,00 & 0,01 \\
Sagu & 0,06 & 0,04 & 0,06 & 0,03 & 0,03 & 0,04 \\
$\quad$ Hortikultura & 0,01 & 0,00 & 0,01 & 0,01 & 0,00 & 0,01 \\
Bawang merah & & & & & & 0,03 \\
Cabai besar & 0,00 & 0,00 & 0,00 & 0,00 & 0,00 & 0,00 \\
Cabai rawit & 0,12 & 0,11 & 0,06 & 0,04 & 0,04 & 0,08 \\
Kobis & 0,17 & 0,13 & 0,09 & 0,07 & 0,08 & 0,11 \\
Tomat & 0,00 & 0,00 & 0,00 & 0,00 & 0,00 & 0,00 \\
\hline & 0,12 & 0,10 & 0,06 & 0,04 & 0,04 & 0,07 \\
\hline
\end{tabular}

nilai LQ tertinggi adalah kelapa sawit dengan nilai rata-rata LQ 3,69. Komoditas non-padi selain kelapa sawit yang juga mempunyai nilai LQ tinggi adalah komoditi lada. Padi di Kalimantan Timur tidak memiliki keunggulan komparatif dibandingkan dengan komoditas pertanian lainnya.

Berdasarkan analisis LQ tanaman pangan di tingkat nasional, seluruh komoditas tanaman pangan di Kalimantan Timur tidak menjadi komoditas basis wilayah. Begitu juga dengan komoditas hortikultura secara nasional bukan merupakan komoditi basis Kalimantan Timur. Pada penelitian ini, fokus utama swasembada beras Kalimantan Timur adalah komoditas padi, sehingga lebih lanjut akan membahas nilai LQ komoditas padi. Berdasarkan analisis alokasi luas lahan tanaman padi dibandingkan dengan luas total sektor pertanian di Provinsi Kalimantan Timur, maka tanaman padi bukan merupakan komoditas basis. Hal ini terlihat dari nilai LQ komoditas padi, baik untuk masing-masing jenis padi maupun secara total memiliki nilai lebih kecil dari satu (Tabel 1). Artinya, komoditas padi di Kalimantan Timur belum menjadi spesialisasi kegiatan masyarakat dan belum mendapat alokasi penggunaan lahan yang memadai. Hal tersebut mengindikasikan bahwa komoditas padi belum memiliki potensi untuk dikembangkan lebih lanjut di Kalimantan Timur.

Lebih lanjut LQ juga dihitung di tingkat kabupaten di Provinsi Kalimantan Timur. Hasil perhitungan LQ ditingkat kabupaten lebih bervariasi. Pada Tabel 2 disajikan jumlah kabupaten menurut nilai LQ. Dari tabel tersebut terlihat bahwa padi sawah terkonsentrasi di 4 kabupaten/kota yaitu Kabupaten Penajam Paser Utara, Kabupaten Kutai Kartanegara, Kota Samarinda, dan Kota Bontang. Nilai LQ padi relatif lebih rendah dibandingkan komoditi yang lainnya. Komoditi tanaman pangan memiliki nilai LQ relatif lebih tinggi 
Tabel 2. Jumlah Kabupaten Menurut Nilai LQ dan Jenis Komoditas di Provinsi Kalimantan Timur

\begin{tabular}{|c|c|c|c|}
\hline \multirow{2}{*}{ Komoditas } & \multicolumn{2}{|c|}{ Jumlah Kabupaten } & \multirow{2}{*}{ Rata-rata LQ } \\
\hline & $\mathrm{LQ}<1$ & $\mathrm{LQ}>1$ & \\
\hline \multicolumn{4}{|c|}{ Tanaman Pangan } \\
\hline Padi sawah & 6 & 4 & 1,31 \\
\hline Padi ladang & 0 & 0 & 0,33 \\
\hline Jagung & 4 & 6 & 2,52 \\
\hline Kedelai & 6 & 4 & 1,20 \\
\hline Kacang hijau & 8 & 2 & 0,66 \\
\hline Kacang tanah & 5 & 5 & 1,99 \\
\hline Ubi kayu & 4 & 6 & 4,42 \\
\hline Ubi jalar & 4 & 6 & 2,29 \\
\hline \multicolumn{4}{|l|}{ Perkebunan } \\
\hline Kakao & 7 & 3 & 1,85 \\
\hline Lada & 7 & 3 & 1,02 \\
\hline Kopi & 5 & 5 & 1,31 \\
\hline Karet & 4 & 6 & 1,82 \\
\hline Kelapa sawit & 7 & 3 & 0,68 \\
\hline Kelapa & 3 & 7 & 2,36 \\
\hline \multicolumn{4}{|l|}{ Hortikultura } \\
\hline Bawang merah & 7 & 3 & 1,39 \\
\hline Cabai besar & 5 & 5 & 1,52 \\
\hline Cabai rawit & 5 & 5 & 2,22 \\
\hline Kubis & 7 & 3 & 1,42 \\
\hline Tomat & 0 & 0 & 0,03 \\
\hline
\end{tabular}

dari komoditi padi sawah yaitu jagung, kacang tanah, ubi kayu dan ubi jalar. Komoditi jagung, ubi kayu dan ubi jalar relatif menjadi konsentrasi pada 6 kabupaten/kota di Provinsi Kalimantan Timur.

Berdasarkan nilai LQ komoditi perkebunan, nilai LQ padi lebih rendah dibandingkan komoditi kakao, karet dan kelapa. Komoditi karet dan kelapa relatif dominan menjadi basis di kabupaten/kota. Komoditi karet mendominasi 6 kabupaten/kota sedangkan kelapa mendominasi 7 kabupaten/kota. Begitu juga dengan komoditi hortikultura nilai LQ komoditi bawang merah, cabai besar, cabai rawit, dan kobis lebih tinggi dibandingkan nilai LQ padi sawah. Jika secara nasional komoditi kelapa sawit menjadi basis Provinsi Kalimantan Timur, namun pada tingkat kabupaten komoditi perkebunan selain sawit menjadi komoditas basis beberapa kabupaten. Hal ini menyebabkan nilai LQ komoditi lain menjadi lebih tinggi dibanding kelapa sawit.

Hal yang menarik disini adalah posisi Kota Samarinda dan Kota Bontang yang memiliki nilai LQ komoditas padi relatif tinggi. Padahal secara empiris Kota Samarinda dan Bontang memiliki total luas lahan pertanian relatif kecil dan tidak dominan dibandingkan Kabupaten Penajam Paser Utara dan Kutai Kartanegara. Hal ini terjadi karena porsi luas lahan padi Kota Samarinda dan Bontang terhadap luas lahan pertanian kota tersebut relatif lebih besar dibanding porsi luas lahan padi provinsi terhadap luas lahan pertanian provinsi. Oleh karena itu dalam konteks pengembangan komoditas, besaran LQ di tingkat kabupaten perlu memperhatikan posisi komoditas tersebut di tingkat provinsi. Nilai LQ yang tinggi tidak mencerminkan luas lahan yang lebih luas, tetapi cerminan dari nilai relatif porsi luas lahan komoditas padi dalam wilayah tersebut (Hendayana 2003).

Kelapa sawit selain menjadi komoditas basis provinsi juga menjadi basis di Kabupaten Berau, Kutai Timur dan Paser. Artinya kelapa sawit di ketiga kabupaten tersebut dominan. Meskipun hanya tiga kabupaten yang menjadi basis kelapa sawit, namun demikian kelapa 
sawit lebih berperan dalam kontribusi terhadap perekonomian wilayah dan menjadi spesialisasi kegiatan ekonomi Provinsi Kalimantan Timur. Pada Tabel 3 disajikan kabupaten berdasarkan pada jenis komoditi basisnya.

Pengembangan tanaman padi yang tidak kompetitif di tingkat kabupaten harus mengorbankan komoditas basis di kabupaten tersebut. Terlihat bahwa di kabupaten basis komoditi padi, juga terdapat komoditi lain sebagai basis. Kota Samarinda selain menjadi basis padi sawah, juga menjadi basis komoditi jagung, kedelai, kacang tanah, ubi kayu, ubi jalar, Lada, kopi, karet, kelapa, cabai besar dan cabai rawit. Kabupaten Penajam Paser Utara komoditi padi bersaing dengan jagung, kedelai, kacang tanah, ubi kayu, ubi jalar, lada, karet, kelapa, cabai besar, dan kobis. Kota Bontang memiliki komoditi basis selain padi yaitu jagung, kacang tanah, ubi kayu, ubi jalar,
Kopi, karet, kelapa, cabai besar, cabai rawit. Sama halnya dengan kabupaten Kutai Kartanegara, memiliki komoditi basis Padi sawah, jagung, kedelai, kacang hijau, kacang tanah, ubi kayu, lada, kopi, kelapa, cabai besar, cabai rawit. Keempat kabupaten/kota basis padi tersebut, padi merupakan bukan satusatunya komoditi basis.

Kabupaten sentra pengembangan padi yang ditetapkan SK Menteri Pertanian Nomor 472/Kpts/Rc.040/6/2018 hanya dua yang memiliki kesesuaian potensi antara SK Menteri Pertanian dengan hasil perhitungan LQ yaitu Kabupaten Penajam Paser Utara dan Kutai Kertanegara. Kabupaten Paser tidak memiliki potensi sebagai kawasan pengembangan komoditas padi karena komoditas basis di kabupaten tersebut adalah kelapa sawit, kopi dan bawang merah. Oleh karena itu komoditas padi berpotensi dikembangkan di Kabupaten Penajam Paser Utara dan Kutai Kartanegara.

Tabel 3. Jumlah Kabupaten Menurut Nilai LQ dan Jenis Komoditas di Provinsi Kalimantan Timur

\begin{tabular}{|c|c|c|c|}
\hline \multirow{2}{*}{ Kabupaten/Kota } & \multicolumn{3}{|c|}{ Komoditi basis } \\
\hline & Tanaman Pangan & Perkebunan & Hortikultura \\
\hline Samarinda & $\begin{array}{l}\text { Padi sawah, jagung, kedelai, } \\
\text { kacang tanah, ubi kayu, ubi jalar }\end{array}$ & $\begin{array}{l}\text { Lada, kopi, karet, } \\
\text { kelapa }\end{array}$ & $\begin{array}{l}\text { Cabai besar, } \\
\text { cabai rawit }\end{array}$ \\
\hline $\begin{array}{l}\text { Penajam Paser } \\
\text { Utara }\end{array}$ & $\begin{array}{l}\text { Padi sawah, jagung, kedelai, } \\
\text { kacang tanah, ubi kayu, ubi jalar }\end{array}$ & $\begin{array}{l}\text { Lada, karet, } \\
\text { kelapa }\end{array}$ & $\begin{array}{l}\text { Cabai besar, } \\
\text { Kobis }\end{array}$ \\
\hline Bontang & $\begin{array}{l}\text { Padi sawah, jagung, kacang tanah, } \\
\text { ubi kayu, ubi jalar }\end{array}$ & Kopi, karet, kelapa & $\begin{array}{l}\text { Cabai besar, } \\
\text { cabai rawit }\end{array}$ \\
\hline Kutai Kartanegara & $\begin{array}{l}\text { Padi sawah, jagung, kedelai, } \\
\text { kacang hijau, kacang tanah, ubi } \\
\text { kayu }\end{array}$ & Lada, Kopi, kelapa & $\begin{array}{l}\text { Cabai besar, } \\
\text { cabai rawit }\end{array}$ \\
\hline Paser & - & Sawit, Kopi, & $\begin{array}{l}\text { Bawang } \\
\text { merah }\end{array}$ \\
\hline Berau & $\begin{array}{l}\text { Jagung, kedelai, kacang hijau, } \\
\text { kacang tanah, ubi jalar }\end{array}$ & $\begin{array}{l}\text { Sawit, kakao, lada, } \\
\text { kelapa }\end{array}$ & $\begin{array}{l}\text { Bawang } \\
\text { merah, } \\
\text { Kobis }\end{array}$ \\
\hline Kutai Timur & - & Sawit, Kakao & - \\
\hline Kutai Barat & Ubi kayu & Kopi, Karet & \\
\hline Balikpapan & $\begin{array}{l}\text { Jagung, Kacang tanah, ubi kayu, } \\
\text { ubi jalar }\end{array}$ & $\begin{array}{l}\text { Lada, kopi, karet, } \\
\text { kelapa }\end{array}$ & $\begin{array}{l}\text { Cabai besar, } \\
\text { cabai rawit, } \\
\text { kobis }\end{array}$ \\
\hline Mahulu & Ubi kayu & $\begin{array}{l}\text { Kakao, kopi, karet, } \\
\text { kelapa }\end{array}$ & \\
\hline
\end{tabular}


Prospek swasembada beras di Kalimantan Timur lebih lanjut dapat dilakukan dengan meningkatkan produksi padi di Kabupaten Penajam Paser Utara dan Kutai Kartanegara. Kabupaten lainnya yaitu Berau, Kutai Timur, Kutai Barat dan Mahulu berdasarkan proporsi penggunaan luas lahan pertanian, saat ini belum memiliki potensi sebagai kabupaten basis padi.

Dari analisis komoditas basis di atas dapat disimpulkan bahwa padi tidak potensial untuk dikembangkan di Provinsi Kalimantan Timur. Keputusan mengembangkan komoditi padi akan lebih sulit, karena harus mengorbankan komoditi basis di setiap wilayah. komodti padi berkompetisi dengan komoditi non padi. Baik komoditi tanaman pangan, perkebunan dan hortikultura. Opportunity cost mengembangkan padi dalam rangka swasembada beras di tingkat kabupaten dan tingkat provinsi menjadi sangat mahal.

\section{PROSPEK SWASEMBADA BERAS BERDASARKAN FAKTOR PRODUKSI DAN EFISIENSI TEKNIS USAHATANI PADI}

Prospek swasembada beras di Provinsi Kalimantan Timur selanjutnya dijelaskan dari potensi pengembangan padi berdasarkan faktor produksi dan efisiensi teknis. Faktorfaktor produksi dianalisis dengan fungsi produksi translog. Pendugaan fungsi produksi translog dengan metode stochastic frontier menghasilkan fungsi produksi cukup baik, R-square 0,75, dan memiliki nilai koefisien parameter dugaan 8,32 secara statistik nyata pada taraf nyata 0,01 persen.
Dari fungsi produksi translog diperoleh elastisitas penggunaan input seperti tercantum pada Tabel 4. Berdasarkan Tabel 4, Pupuk N memiliki nilai elastisitas paling tinggi dibanding input yang lain. Produksi paling responsif terhadap penambahan pupuk $\mathrm{N}$. Pupuk N yang ditambahkan sebsesar satu persen akan meningkatkan produksi sebesar 1,15 persen. Oleh karena itu peningkatan produksi padi lebih tinggi jika dilakukan penambahan penggunaan pupuk yang mengandung unsur $\mathrm{N}$ (nitrogen) seperti ZA, Urea, dan NPK. Produksi padi kurang responsif terhadap variabel luas lahan, pupuk $\mathrm{P}$, dan pupuk K. Namun, dibanding pupuk $\mathrm{P}$ dan pupuk K, produksi padi lebih responsif terhadap penambahan luas lahan. Oleh karena itu, penambahan areal luas lahan juga dapat menjadi alternatif untuk meningkatkan produksi padi. Produksi padi tidak responsif terhadap variabel benih dan tenaga kerja. Penambahan benih dan tenaga kerja menyebabkan jumlah produksi padi menurun. Hal tersebut menunjukkan bahwa penggunaan benih dan tenaga kerja pada saat itu sudah berlebih.

Analisis penggunaan input usahatani padi di Provinsi Kalimantan Timur menunjukkan bahwa penggunaan pupuk N, P dan K (Tabel 5) lebih rendah dibandingkan dengan dosis yang direkomendasikan pemerintah. Menurut Permentan Nomor 40 tahun 2007, pada satu hektar lahan dengan tingkat kesuburan rendah memerlukan $115 \mathrm{~kg}$ pupuk $\mathrm{N}, 36 \mathrm{~kg}$ pupuk $\mathrm{P}$ dan $56,25 \mathrm{~kg}$ pupuk K. Oleh karena itu peningkatan produksi dapat dilakukan dengan menambah dosis penggunaan pupuk $\mathrm{N}, \mathrm{P}$, dan $\mathrm{K}$ sesuai dengan yang dianjurkan. Sebaliknya penggunaan benih

Tabel 4. Elastisitas Variabel Input Produksi Padi di Provinsi Kalimantan Timur

\begin{tabular}{lc}
\hline \multicolumn{1}{c}{ Variabel Input Produksi } & Nilai elastisitas \\
\hline Luas lahan & 0,92 \\
Benih & $-0,33$ \\
Pupuk N & 1,15 \\
Pupuk P & 0,12 \\
Pupuk K & 0,32 \\
Tenaga kerja & $-0,54$ \\
\hline
\end{tabular}


Tabel 5. Rata-rata Penggunaan Input Usahatani Padi Sawah di Provinsi Kalimantan Timur

\begin{tabular}{lccl}
\hline \multicolumn{1}{c}{ Variabel input } & Rata-rata & Maksimal & Minimal \\
\hline Luas lahan (ha) & 1,15 & 5,00 & 0,075 \\
Benih (kg/ha) & 39,52 & 80,00 & 2,50 \\
Pupuk N (kg/ha) & 65,28 & 228,50 & 0,30 \\
Pupuk P (kg/ha) & 26,30 & 120,00 & 0,20 \\
Pupuk K (kg/ha) & 20,16 & 108,00 & 0,20 \\
Tenaga kerja (HOK/ha) & 55,03 & 222,00 & 5,33 \\
\hline
\end{tabular}

melebihi dosis yang dianjurkan. Badan Litbang Pertanian merekomendasikan penggunaan benih $25 \mathrm{~kg}$ per hektar, lebih rendah dari rata-rata penggunaan benih di petani $(39,52 \mathrm{~kg}$ per hektar). Sama halnya dengan penggunaan tenaga kerja lebih tinggi di banding rata-rata penggunaan tenaga kerja nasional yaitu $47 \mathrm{HOK}$ per hektar (Haryanto et al. 2016). Analisis efisiensi teknis menunjukkan rata-rata efisien teknis sebesar 0,64 dengan produktivitas rata-rata sebesar 3,14 ton/ha (Tabel 6). Hasil tersebut, menunjukkan bahwa rata-rata petani berproduksi 34 persen di bawah tingkat produksi yang efisien (frontier). Dalam konteks potensi peningkatan produksi, dengan teknologi yang sama masih memung- kinkan untuk meningkatkan produksi sebesar 34 persen.

Selanjutnya pada Tabel 7 disajikan nilai LQ padi dan efisiensi teknis berdasarkan kabupaten di Provinsi Kalimantan Timur. Pada tabel terlihat Kota Samarinda dan Kabupaten Kutai Kartanegara dengan nilai LQ tinggi mempunyai nilai efisiensi teknis lebih besar dari 0,70, artinya kedua kabupaten/kota tersebut sudah efisien secara teknis namun masih dapat ditingkatkan sebesar 22 persen dan 24 persen. Kabupaten/Kota Penajam Paser Utara dan Bontang menunjukkan belum efisien secara teknis dengan nilai efisiensi teknis 0,55 dan 0,51. Hal tersebut menunjukkan bahwa Kabupaten/kota basis padi tersebut memiliki peluang yang lebih tinggi

Tabel 6. Jumlah Petani Menurut Selang Nilai Efisiensi, Rata-rata Efisiensi, dan Produktivitas Padi

\begin{tabular}{ccccc}
\hline $\begin{array}{c}\text { Selang Nilai } \\
\text { Efisiensi }\end{array}$ & $\begin{array}{c}\text { Jumlah } \\
\text { petani }\end{array}$ & $\begin{array}{c}\text { Persen } \\
\mathbf{( \% )}\end{array}$ & $\begin{array}{c}\text { Rata-rata Efisiensi } \\
\text { Teknis }\end{array}$ & $\begin{array}{c}\text { Rata-rata } \\
\text { Produktivitas } \\
\text { (ton/ha) }\end{array}$ \\
\hline$<0,3$ & 42 & 12 & 0,20 & 1,04 \\
$0,3-0,49$ & 57 & 17 & 0,41 & 2,09 \\
$0,5-0,69$ & 88 & 26 & 0,61 & 3,01 \\
$\geq 0,7$ & 150 & 45 & 0,86 & 4,19 \\
Total & 337 & 100 & 0,64 & 3,14 \\
\hline
\end{tabular}

Tabel 7. Nilai LQ Padi Sawah, Jumlah Petani, dan Efisiensi Teknis Berdasarkan Kabupaten di Provinsi Kalimantan Timur

\begin{tabular}{lccc}
\hline \multicolumn{1}{c}{ Kabupaten } & LQ rata-rata & Jumlah petani & Rata-rata efisiensi teknis \\
\hline Samarinda & 5,99 & 35 & 0,78 \\
Penajam Paser Utara & 2,36 & 81 & 0,55 \\
Bontang & 1,67 & 9 & 0,51 \\
Kutai Kartanegara & 1,67 & 2 & 0,76 \\
Paser & 0,49 & 25 & 0,55 \\
Berau & 0,47 & 141 & 0,74 \\
Kutai Timur & 0,15 & 12 & 0,70 \\
Kutai Barat & 0,14 & 32 & 0,36 \\
Balikpapan & 0,10 & 0 & 0,00 \\
Mahulu & 0,05 & 0 & 0,00 \\
\hline
\end{tabular}


untuk ditingkatkan sebesar 45 persen dan 49 persen. Hasil analisis efisiensi teknis juga menunjukkan kabupaten nonbasis sudah efisien secara teknis yaitu Kabupaten Berau dan kutai Timur. Hasil analisis ini menunjukkan bahwa pengembangan padi di satu kabupaten perlu mempertimbangkan baik potensi wilayah maupun efisiensi produksi.

Efisiensi teknis dapat ditingkatkan dengan peningkatan variabel-variabel yang menentukan efisiensi. Variabel yang diduga mempengaruhi efisiensi teknis pada penelitian ini yaitu persentase penggunaan kredit, dummy penyuluhan, dummy irigasi, dummy pola tanam, dummy alat dan dummy status lahan. Hasil pendugaan variabel inefisiensi (Tabel 8) menunjukkan terdapat lima variabel yaitu dummy penyuluhan, dummy irigasi, dummy pola tanam, dummy alat dan dummy status lahan berpengaruh signifikan terhadap efisiensi teknis. Variabel kredit tidak berpengaruh terhadap efisiensi teknis meskipun hasil estimasi bertanda negatif. Diduga pada saat penelitian persentase penggunaan kredit belum berperan terhadap efisiensi.

Petani yang menggunakan pola tanam lebih dari satu kali dalam setahun lebih efisien dibandingkan dengan pola tanam satu kali dalam setahun. Begitu juga dengan variabel dummy status kepemilikan lahan, memengaruhi peningkatan efisiensi. Petani yang menggarap lahan milik sendiri lebih efisien dibandingkan lahan sewa dan lainnya (lahan pinjaman, dan lahan kelompok). Hal ini disebabkan karena keputusan petani untuk mengolah lahan milik sendiri mempertimbangkan status keberlanjutan lahan miliknya, sejalan dengan penelitian (Apriani et al.
2018). Kepemilikan lahan membuat petani peduli terhadap keberlanjutan usahatani dan lebih berhati-hati dalam mengolah lahannya. Petani akan memanfaatkan lahan milik sendiri dengan sebaik-baiknya karena rasa memiliki (Kusnadi et al. 2011; Delwina et al. 2019). Irigasi diharapkan meningkatkan efisiensi teknis usahatani padi di Indonesia sehingga harus dipertimbangkan dalam kebijakan pemerintah (Haryanto et al. 2016). Berbeda dengan hasil penelitian ini, irigasi menurunkan efisiensi teknis usahatani padi di Kalimantan Timur. Begitu juga dengan dummy penyuluhan, dan dummy alat secara nyata menurunkan efisiensi teknis. Kelompok petani yang mengolah lahan irigasi, mengikuti penyuluhan dan menggunaan alat traktor tidak efisien dalam usahataninya. Hal ini disebabkan oleh kondisi petani di lapangan, masih banyak tidak mengolah lahan irigasi, tidak mengikuti penyuluhan dan menggunakan alat tenaga hewan dan manusia. Kelompok petani yang mengolah sawah irigasi, mengikuti penyuluhan, dan menggunakan traktor masih menimbulkan keragaman produksi, dan masih banyak petani berproduksi di bawah frontiernya.

Prospek swasembada beras yang diukur melalui produksi dan efisiensi teknis, menunjukkan kondisi saat ini petani belum mencapai tingkat produksi maksimum dan efisien secara teknis. Artinya pada tingkat teknologi yang sama, berpotensi meningkatkan produksi dan memiliki peluang yang tinggi untuk meningkatkan efisiensi teknis. Produksi masih responsif terhadap luas lahan, pupuk N, P, dan K. Peningkatan produksi dilakukan dengan meningkatkan penggunaan variabel tersebut. Namun pupuk $\mathrm{N}$ paling

Tabel 8. Hasil Analisis Pendugaan Variabel Inefisiensi Usahatani Padi di Kalimantan Timur

\begin{tabular}{lcc}
\hline \multicolumn{1}{c}{ Variabel inefisiensi } & Koefisien & $\operatorname{Pr}(>|\mathbf{z}|)$ \\
\hline Kredit & $-0,003$ & 0,444 \\
Dummy penyuluhan & $0,156^{*}$ & 0,084 \\
Dummy irigasi & $0,619^{* * *}$ & 0,000 \\
Dummy pola tanam & $-1,220^{* * *}$ & 0,000 \\
Dummy alat & $0,784^{* * *}$ & 0,000 \\
Dummy status lahan & $-0,257^{* *}$ & 0,003 \\
\hline Keterangan: ${ }^{*}=$ signifikan pada taraf nyata 10 persen, & & \\
$\quad * *$ signifikan pada taraf nyata 1 persen, & &
\end{tabular}


elastis sehingga dianjurkan untuk menambahkan dosis pupuk yang mengandung unsur $\mathrm{N}$ (nitrogen). Peningkatan efisiensi dapat dilakukan dengan pola tanam lebih dari satu kali dalam setahun dan mengolah lahan milik sendiri. Pola tanam lebih dari satu kali dalam setahun bergantung pada ketersediaan air. Oleh karena itu sistem irigasi perlu ditingkatkan agar mencukupi kebutuhan air, meskipun kondisi saat ini irigasia belum berperan meningkatkan efisiensi teknis. Variabel kredit saat ini belum berperan dalam meningkatkan efisiensi, maka masih perlu adanya perbaikan dalam penggunaannya. Pencapaian swasembada beras tidak terlepas dari kebijakan pemerintah Provinsi Kalimantan Timur. Sehingga dibutuhkan kebijakan dari pemerintah Provinsi Kalimantan Timur, terhadap upaya peningkatan produksi padi terutama dalam penggunaan input produksi dan fasilitas usahatani padi. Penggunaan irigasi, penyuluhan, dan alat (traktor) menurunkan efisiensi teknis dan masih menimbulkan keragaman produksi padi di Kalimantan Timur.

\section{KESIMPULAN DAN SARAN}

\section{KESIMPULAN}

Provinsi Kalimantan Timur belum memiliki potensi untuk mencapai swasembada beras. Dilihat dari prospeknya, dari aspek produksi berdasarkan komoditas basis dan efisiensi teknis kondisi saat ini swasembada beras di Provinsi Kalimantan Timur belum didukung oleh potensi wilayah dan produksi yang efisien, yaitu:

1. Berdasarkan analisis LQ tingkat nasional, secara ekonomi padi bukan merupakan komoditas basis di Kalimantan Timur. Pada tingkat provinsi, padi menjadi komoditi basis di 4 kabupaten/kota namun hanya berpotensi dikembangkan di 2 kabupaten. Komoditi Padi berpotensi untuk dikembangkan lebih lanjut di Kabupaten Penajam Paser Utara dan Kabupaten Kutai Kartanegara.
2. Usahatani di Kalimantan Timur menunjukkan belum efisien secara teknis. Faktor yang memengaruhi efisiensi teknis usahatani padi di Kalimantan Timur yaitu pola tanam lebih dari satu kali dalam setahun dan pengolahan lahan milik sendiri.

\section{SARAN}

Hasil penelitian ini diharapkan dapat menjadi rumusan kebijakan swasembada beras di Provinsi Kalimantan Timur yaitu sebagai berikut :

1. Prospek swasembada beras Kalimantan Timur, memungkinkan untuk dicapai jika mengembangkan komoditi padi sebagai basis Provinsi dan meningkatkan produksi melalui efisiensi teknis.

2. Perlu adanya kebijakan lebih lanjut dari pemerintah provinsi untuk mengalokasikan luas lahan pertanian lebih banyak untuk komoditi padi jika ingin menjadikan padi sebagai komoditi basis.

3. Peningkatan efisiensi teknis dapat dilakukan dengan pengaturan pola tanam lebih dari satu kali dan mengolah lahan milik sendiri.

4. Diharapkan petani di Kalimantan Timur menggunakan pola tanam lebih dari satu kali dalam setahun agar usahataninya lebih efisien, dan pemerintah seharusnya memberikan fasilitas irigasi agar memenuhi kebutuhan pengairan untuk produksi padi.

\section{DAFTAR PUSTAKA}

Apriani M, Rachmina D, Rifin A. 2018. Pengaruh tingkat penerapan teknologi pengolahan tanaman terpadu (PTT) terhadap efisiensi teknis usahatani padi. Jurnal Agribisnis Indonesia. 6 (2):121-132

Ariani M. 2010. Diversifikasi Konsumsi Pangan Pokok Mendukung Swasembada Beras. Prosiding Pekan Serealia Nasional. Maros, 20 Juli 2010. Badan litbang pertanian. 29 (3) 978-979 
[BPS] Badan Pusat Statistik Kalimantan Timur. 2018. Luas Panen dan Produksi Padi Provinsi Kalimantan Timur. [Internet]. [Diunduh pada 2019 Juli 16]. Tersedia pada https:/ / kaltim.bps.go.id/

[BPS] Badan Pusat Statistik. 2019. Berita Resmi (BRS) Luas Panen dan Produksi Padi Indonesia. Jakarta (ID): Badan Pusat Statistik

Christensen LR, Jorgensen DW, Lau LJ. 1973. Transcedental logarithmic production frontiers. The review of Economic and Statistic 55 (1):28-45

Coelli TJ, Rao DSP, Donell CJ, Battese G. 2005. An Introduction to Efficiency and Productivity Analysis Second Edition. New York: Springer Scince Business Media Inc.

Delwina D, Jamhari, Waluyati LR. 2019. Dampak kepemilikan lahan padi sawah terhadap efisiensi teknis dan efisiensi lingkungan di Kabupaten Rokan Hulu. Journal of Agribusiness and Rural Development Research. 5 (1):79-87

[Dispertan] Dinas Pangan Tanaman Pangan dan Hortikultura. 2018. Laporan Tahunan Dinas Pangan, Tanaman Pangan dan Hortikultura Provinsi Kalimantan Timur Tahun 2018. [Internet]. [Diunduh pada 2019 Juli 09] Tersedia pada http:/ / dispertan.kaltimprov.go.id/

Farrell M. 1957. The measurement of productive efficiency. Journal of the Royal Statistical Society, Series A, General, 3 (120):253-81

Guo H dan Marchand S. 2014. The environmental efficiency of non-certified organic farming in China : A case study of paddy rice production. China Economic Review, 31:201-216.

Haryanto T, Talib BA, Salleh NHM. 2016. Technical Efficiency and Technology Gap in Indonesian Rice Farming. Agris on-line Papers in Economics and Informatics. 8 (3):25-52

Hendayana R. 2003. Aplikasi Metode Location Qoutient (LQ) dalam Penentuan
Komoditas Unggunal Nasional. Jurnal Informatika Pertanian. 12:1-21

Kasryno F, M Badrun, E Pasandaran. 2011. Land Grabbing Perampasan Hak Konstitusional Masyarakat. YAPARIYayasan Pertanian Mandiri.

[Kementan] Kementerian Pertanian RI. 2007. Peraturan Mentan No. 40/Permentan/OT.140/04/2007 Tentang Rekomendasi Pemupukan N, P dan K pada Padi Sawah Spesifik Lokasi. Jakarta (ID): Badan Litbang Pertanian.

[Kementan] Kementerian Pertanian RI. 2018. Keputusan Menteri Pertanian Republik Indonesia Nomor 472/Kpts/Rc.040/6/2018 Tentang Lokasi Kawasan Pertanian Nasional. Jakarta (ID): Kementerian Pertanian

Kusnadi N, Tinaprilla N, Susilowati SH, Purwoto A. 2011. Analisis efisiensi usahatani padi di beberapa sentra produksi padi di Indonesia. Jurnal Agro Ekonomi. 29 (1):25 - 48

Mulyono J dan Munibah K. 2016. Pendekatan Location Quotient dan Shif Share Analysis dalam Penentuan Komoditas Unggulan Tanaman Pangan di Kabupaten Bantul. Informatika Pertanian 3 (2):221-230

[Pergub] Peraturan Gubernur Kalimantan Timur. 2016. Pergub Kaltim Nomor 50 Tahun 2016 tentang Penyesuaian RPJMD Tahun 2013-2018. [Internet]. [Diunduh pada 2019 Juli 09]. Tersedia pada https://peraturan.bpk.go.id

Setiyanto A. 2013. Pendekatan dan Implementasi Pengembangan Kawasan Komoditas Unggulan Pertanian. Forum Penelitian Agro Ekonomi 31 (2):71-95 